\title{
Thioxopyrimidine in Heterocyclic Synthesis III: Synthesis and Properties of Some Novel Heterocyclic Chalcone Derivatives Containing a Thieno $[2,3-d]$ pyrimidine-Based Chromophore
}

\author{
Yuh Wen Ho ${ }^{1}$ and Wei Hua Yao ${ }^{2}$ \\ ${ }^{1}$ Department of Creative Fashion Design, Taoyuan Institute of Innovation Technology, Jhongli, 32091, Taiwan \\ ${ }^{2}$ Department of Materials and Textiles, Oriental Institute of Technology, Pan-Chiao 22064, Taiwan
}

Correspondence should be addressed to Yuh Wen Ho; wen@tiit.edu.tw

Received 29 June 2012; Accepted 26 November 2012

Academic Editor: Jacques Lalevee

Copyright (C) 2013 Y. W. Ho and W. H. Yao. This is an open access article distributed under the Creative Commons Attribution License, which permits unrestricted use, distribution, and reproduction in any medium, provided the original work is properly cited.

\begin{abstract}
Cyclization of 4-methyl-2-phenyl-6-thioxo-1,6-dihydropyrimidine-5-carbonitrile 1 with chloroacetone in DMF in the presence of excess potassium carbonate anhydrous gave the 1-(5-amino-4-methyl-2-phenylthieno[2,3-d]pyrimidin-6-yl)ethanone 3, which can react with 2,5-dimethoxytetrahydrofuran in glacial acetic acid producing the 1-[4-methyl-2-phenyl-5-(1H-pyrrol-1-yl)thieno[2,3d]pyrimidin-6-yl]ethanone 4. On the other hand, a series of novel 3-aryl-1-[4-methyl-2-phenyl-5-(1H-pyrrol-1-yl)-thieno[2,3d]pyrimidin-6-yl]prop-2-en-1-one chalcone dyes $\mathbf{6 a}-\mathbf{n}$ were obtained by the condensation reaction of 1-[4-methyl-2-phenyl5(1H-pyrrol-1-yl)thieno[2,3-d]-pyrimidin-6-yl]ethanone 4 with appropriate aldehydes. The structures of chalcone dyes were characterized by IR, ${ }^{1} \mathrm{H}$ NMR, mass, elemental analysis, and UV-Vis spectroscopy. The dyes were applied to polyester fibers for creating hues ranging from greenish-yellow to orange; their spectral characteristics, substituent effect in DMF solution, fastness properties, and colorimetric assessment are also discussed.
\end{abstract}

\section{Introduction}

The considerable biological and medicinal activity caused by fused thienopyrimidines has stimulated much research in this field [1-5]. Moreover, several series of heterocyclic compounds possessing a bridgehead pyrrolic moiety play a vital role in many biological activities [6-10]. Likewise, compounds with a chalcone-based structure have showed an array of pharmacological activities [11-16]. However, chalcones, the bichromophoric molecules separated by vinyl chains and the carbonyl group, are found being effective photosensitive materials and exhibit promising nonlinear optical properties [17]. On the other hand, molecular twophoton absorption (TPA) has attracted a lot of interest recently for its applications in the field of both biological imaging and materials science; TPA materials have recently received considerable attention [18-20]. A number of organic molecules have been studied for TPA activity [21-24]. Among these TPA systems, the heterocycle-based chromophores are particularly interesting due to their easily polarizable heteroaromatic rings which can help to improve their degree of intramolecular charge transfer (ICT) [2527]. Recently the synthesis and characterization of chromophores have been reported in which the donor moiety is represented by a $\pi$-excessive five-membered heterocycle (pyrrole or thiophene) and the acceptor group is a deficient heterocyclic azine ring (pyridine, pyrazine, pyrimidine, and pyridazine), which exhibit solvatochromic, electrochromic, photochromic, fluorescent, and nonlinear optical properties $[28,29]$. Further developments involve the stretch of the charge transfer and the length of the $\pi$-bridge, such as multibranched octupoles or dendrimers [30].

Beyond these very important applications in biological chemistry, the chalcones are also found being used in the production of nematic liquid crystals [31], photosensitive polymers [32], antioxidants [33, 34], and as dyes [35, 36]. Although a number of papers concerning the synthesis of chalcone compounds have been published, those containing a new heterocyclic system of thieno[2,3- $d]$-pyrimidinebased chromophores and application have not yet been 
reported. Therefore, based on our previous works [37-39], we aim to report herein the preparation of a series of chalcone derivatives containing a thieno[2,3- $d]$-pyrimidinebased chromophore, and there was application to polyester fibers as disperse dyes. The spectral characteristics, dyeing properties, and colorimetric assessment of the dyes are also discussed.

\section{Experimental}

2.1. General. All melting points are uncorrected and in ${ }^{\circ} \mathrm{C}$. IR spectra were recorded on a JASCO FTIR- 3 spectrometer $(\mathrm{KBr}) ;{ }^{1} \mathrm{H}$ NMR spectra were obtained on a Bruker AM-300 WB FI-NMR spectrometer, and chemical shifts are expressed in $\delta$ ppm using TMS as an internal standard. Electron impact mass spectra were obtained at $70 \mathrm{eV}$ using a Finnigan Mat TSQ-46C spectrometer. Elemental analyses were performed on a Perkin-Elmer 240 elemental Analyzer. Electronic spectra were recorded on a Shimadzu UV 240 from dye solutions in DMF at a concentration of $2 \times 10^{-5} \mathrm{~mol} \mathrm{~L}^{-1}$. Aldehydes $\mathbf{5 a}-\mathbf{n}$ were purchased from Aldrich and were used without further purification.

2.2. Synthesis of 1-(5-Amino-4-methyl-2-phenylthieno[2,3d]pyrimidin-6-yl)ethanone (3). To a solution of 4-methyl2-phenyl-6-thioxo-1,6-dihydropyrimidine-5-carbo-nitrile 1 $(2.27 \mathrm{~g}, 0.01 \mathrm{~mol})$ in DMF $(50 \mathrm{~mL})$, potassium carbonate anhydrous $(2.76 \mathrm{~g}, 0.02 \mathrm{~mol})$ and chloroacetone $2(0.93 \mathrm{~g}$, $0.01 \mathrm{~mol}$ ) were added. The reaction mixture was stirred at room temperature for $4 \mathrm{~h}$ and then diluted with cold water $(50 \mathrm{~mL})$. The resulting solid product was collected by filtration, washed with water, and recrystallized from ethyl acetate/ethanol to give $2.66 \mathrm{~g}$ of yellow needles ( $94 \%$ yield), m.p. $210^{\circ} \mathrm{C}$; IR: $v$ 3424, $3295\left(\mathrm{NH}_{2}\right), 1663(\mathrm{C}=\mathrm{O}) \mathrm{cm}^{-1}$; ${ }^{1} \mathrm{H} \mathrm{NMR}\left(\mathrm{CDCl}_{3}\right): \delta 2.47\left(3 \mathrm{H}, \mathrm{s}, \mathrm{COCH}_{3}\right), 3.07\left(3 \mathrm{H}, \mathrm{s}, \mathrm{CH}_{3}\right)$, $3.76\left(2 \mathrm{H}, \mathrm{br}, \mathrm{NH}_{2}\right), 8.58-8.55,7.60-7.55(5 \mathrm{H}, \mathrm{m}$, phenyl-H); MS: $283\left(\mathrm{M}^{+}, 100\right), 268$ (95), 240 (20), 212 (2), 165 (5), 160 (10), 137 (34), 110 (18), 77 (9). Anal. Calcd. for $\mathrm{C}_{15} \mathrm{H}_{13} \mathrm{~N}_{3} \mathrm{OS}$ : C, 63.60; H, 4.59; N, 14.84. Found: C, 63.63; H, 4.50; N, $14.77 \%$.

2.3. Synthesis of 1-[4-Methyl-2-phenyl-5-(1H-pyrrol-1-yl) thieno[2,3-d]pyrimidin-6-yl]ethanone (4). A mixture of 1-(5amino-4-methyl-2-phenylthieno[2,3-d]pyrimidin-6-yl)ethan-one 3 (2.83 g, $0.01 \mathrm{~mol}), 2,5$-dimethoxytetrahydrofuran $(1.26 \mathrm{~g}, 0.01 \mathrm{~mol})$, in glacial acetic acid $(20 \mathrm{~mL})$ was refluxed for $12 \mathrm{~h}$. After cooling, the resulting solid product was collected by filtration, washed with water, and the crude product recrystallized from ethanol/glacial acetic acid to give $2.96 \mathrm{~g}$ of gray white needles $\left(89 \%\right.$ yield), m.p. $204^{\circ} \mathrm{C}$; IR: $v 1660(\mathrm{C}=\mathrm{O}) \mathrm{cm}^{-1} ;{ }^{1} \mathrm{H} \mathrm{NMR}\left(\mathrm{CDCl}_{3}\right): \delta 2.09(3 \mathrm{H}, \mathrm{s}$, $\left.\mathrm{COCH}_{3}\right), 2.20\left(3 \mathrm{H}, \mathrm{s}, \mathrm{CH}_{3}\right), 6.50(2 \mathrm{H}, \mathrm{t}, 3,4-\mathrm{H}$ of pyrrolyl), 6.87 (2H, t, 2,5-H of pyrrolyl), 8.56-8.54, 7.51-7.49 (5H, m, phenyl-H); MS: $333\left(\mathrm{M}^{+}, 100\right), 318$ (35), 290 (36), 277 (4), 223 (4), 185 (8), 166 (10), 160 (14), 116 (10), 103 (20), 77 (19), 51 (5). Anal. Calcd. for $\mathrm{C}_{19} \mathrm{H}_{15} \mathrm{~N}_{3} \mathrm{OS}$ : C, 68.46; H, 4.50; $\mathrm{N}, 12.61$. Found: C, 68.33; H, 4.52; N, 12.59\%.
TABLE 1: Physical and analytical data of 6-(3-substituted-acryloyl)5-(1-pyrrolyl)-4-methyl-2-phenylthieno[2,3-d]pyrimidine derivatives $\mathbf{6 a}-\mathbf{n}$.

\begin{tabular}{|c|c|c|c|c|c|c|}
\hline \multirow{3}{*}{ Dye } & \multirow{3}{*}{$\begin{array}{l}\text { M.P. } \\
\left({ }^{\circ} \mathrm{C}\right)^{\mathrm{a}}\end{array}$} & \multirow{3}{*}{$\begin{array}{l}\text { Yield } \\
(\%)\end{array}$} & \multirow{3}{*}{$\begin{array}{l}\text { Molecular } \\
\text { formula }\end{array}$} & \multirow{2}{*}{\multicolumn{3}{|c|}{$\begin{array}{c}\text { Elemental analysis (\%) } \\
\text { Calcd/Found }\end{array}$}} \\
\hline & & & & & & \\
\hline & & & & $\mathrm{C}$ & $\mathrm{H}$ & $\mathrm{N}$ \\
\hline \multirow{2}{*}{$6 a$} & \multirow{2}{*}{184} & \multirow{2}{*}{88} & \multirow{2}{*}{$\mathrm{C}_{26} \mathrm{H}_{18} \mathrm{ClN}_{3} \mathrm{OS}$} & 68.49 & 3.95 & 9.22 \\
\hline & & & & 68.55 & 4.02 & 9.33 \\
\hline \multirow{2}{*}{$6 b$} & \multirow{2}{*}{282} & \multirow{2}{*}{96} & \multirow{2}{*}{$\mathrm{C}_{28} \mathrm{H}_{24} \mathrm{~N}_{4} \mathrm{OS}$} & 72.41 & 5.17 & 12.06 \\
\hline & & & & 72.58 & 5.21 & 12.12 \\
\hline \multirow{2}{*}{$6 c$} & \multirow{2}{*}{170} & \multirow{2}{*}{96} & \multirow{2}{*}{$\mathrm{C}_{27} \mathrm{H}_{21} \mathrm{~N}_{3} \mathrm{OS}$} & 74.48 & 4.82 & 9.65 \\
\hline & & & & 74.44 & 4.92 & 9.55 \\
\hline \multirow{2}{*}{$6 d$} & \multirow{2}{*}{262} & \multirow{2}{*}{95} & \multirow{2}{*}{$\mathrm{C}_{27} \mathrm{H}_{21} \mathrm{~N}_{3} \mathrm{O}_{2} \mathrm{~S}$} & 71.84 & 4.65 & 9.31 \\
\hline & & & & 71.80 & 4.71 & 9.45 \\
\hline \multirow{2}{*}{$6 e$} & \multirow{2}{*}{230} & \multirow{2}{*}{93} & \multirow{2}{*}{$\mathrm{C}_{30} \mathrm{H}_{28} \mathrm{~N}_{4} \mathrm{OS}$} & 73.17 & 5.69 & 11.38 \\
\hline & & & & 73.22 & 5.74 & 11.24 \\
\hline \multirow{2}{*}{$6 f$} & \multirow{2}{*}{148} & \multirow{2}{*}{95} & \multirow{2}{*}{$\mathrm{C}_{32} \mathrm{H}_{23} \mathrm{~N}_{3} \mathrm{OS}$} & 77.26 & 4.62 & 8.45 \\
\hline & & & & 77.23 & 4.77 & 8.56 \\
\hline \multirow{2}{*}{$6 \mathrm{~g}$} & 130 & 92 & $\mathrm{C}_{2} \mathrm{H}_{17} \mathrm{~N}_{3} \mathrm{O}_{2} \mathrm{~S}$ & 70.07 & 4.13 & 10.21 \\
\hline & & & & 70.15 & 4.22 & 10.36 \\
\hline $6 \mathrm{~h}$ & 262 & 98 & $\mathrm{C}_{2} \mathrm{H}_{17} \mathrm{~N}_{2} \mathrm{OS}_{2}$ & 67.44 & 3.98 & 9.83 \\
\hline & & & & 67.39 & 4.06 & 9.89 \\
\hline $6 \mathbf{i}$ & 278 & 95 & & 79.26 & 4.22 & 7.70 \\
\hline & & & & 79.58 & 4.56 & 7.98 \\
\hline $6 i$ & 178 & 98 & $\mathrm{C} \mathrm{H} \mathrm{N} \mathrm{OS}$ & 75.83 & 4.83 & 10.40 \\
\hline & & & $\mathrm{C}_{34^{11}} \mathrm{~T}^{1 \mathrm{~N}}{ }_{4} \mathrm{U}$ & 75.88 & 4.73 & 10.33 \\
\hline $6 \mathbf{k}$ & 152 & 93 & $\mathrm{C}_{20} \mathrm{H}_{2} \mathrm{~N}_{2} \mathrm{OS}$ & 75.16 & 5.40 & 9.07 \\
\hline & & & $\mathrm{C}_{29} \mathrm{II}_{25} \mathrm{~N}_{3} \mathrm{O}$ & 75.18 & 5.42 & 9.24 \\
\hline 61 & 210 & 84 & $\mathrm{C}_{20} \mathrm{H}_{22} \mathrm{~N}_{4} \mathrm{O}_{2} \mathrm{~S}$ & 70.29 & 4.60 & 11.71 \\
\hline & & & $28^{+}+22^{+}$ & 70.32 & 4.56 & 11.55 \\
\hline $6 \mathrm{~m}$ & 228 & 90 & $\mathrm{C}_{24} \mathrm{H}_{3} \mathrm{~N}_{2} \mathrm{OS}$ & 78.31 & 4.41 & 8.06 \\
\hline & & & $-34{ }^{11} 3^{1}+V_{3}$ & 78.29 & 7.48 & 7.97 \\
\hline $6 n$ & 286 & 94 & $\mathrm{C}_{2} \mathrm{H}_{2} \mathrm{~N}$ OS & 77.55 & 4.76 & 9.52 \\
\hline & & & $38^{1}$ & 77.68 & 4.82 & 9.52 \\
\hline
\end{tabular}

${ }^{\mathrm{a}}$ Recrystallization from DMF/ethanol.

2.4. Synthesis of 3-Aryl-1-[4-methyl-2-phenyl-5(1H-pyrrol1-yl)thieno[2,3-d]pyrimidin-6-yl]prop-2-en-1-ones (6a-n) General Procedure. A mixture of compound 4 (0.33 g, $1.0 \mathrm{mmol})$, appropriate aldehydes $\mathbf{5 a - n}(1.0 \mathrm{mmol})$ and $\mathrm{NaOH}(2.2 \mathrm{mmol})$ in absolute ethanol $(10 \mathrm{~mL})$ was stirred at room temperature for $24 \mathrm{~h}$. The mixture was stirred at room temperature for $24 \mathrm{~h}$. The mixture was acidified with dilute acetic acid, and the precipitated product was collected by filtration, washed with water, and the crude product recrystallized from THF/ethanol. The physical constants and spectral data of compounds $\mathbf{6} \mathbf{a}-\mathbf{n}$ are recorded in Tables 1 and 2.

2.5. Dyeing Procedure [40]. Polyester fabrics were dyed in a laboratory dyeing machine at a liquor ratio of $30: 1$. Dyebath 
TABLE 2: Spectra data of 6-(3-substituted-acryloyl)-5-(1-pyrrolyl)-4-methyl-2-phenyl-thieno[2,3- $d$ ]pyrimidine derivatives 6a-n.

\begin{tabular}{|c|c|c|c|}
\hline Dye & $\begin{array}{c}\text { MS } \\
\left(\mathrm{m} / \mathrm{e} \mathrm{M}^{+}\right)\end{array}$ & $\begin{array}{c}\mathrm{IR} \\
(\mathrm{KBr}) \\
v\left(\mathrm{~cm}^{-1}\right)\end{array}$ & $\begin{array}{l}{ }^{1} \mathrm{H}-\mathrm{NMR}^{\mathrm{a}} \\
\left(\mathrm{CF}_{3} \mathrm{COOD}\right) \\
\delta(\mathrm{ppm})\end{array}$ \\
\hline $6 a$ & 455.5 & $1667(\mathrm{C}=\mathrm{O})$ & $\begin{array}{l}2.20\left(3 \mathrm{H}, \mathrm{s}, \mathrm{CH}_{3}\right), 5.80(1 \mathrm{H}, \mathrm{d}, J=3.1 \mathrm{~Hz}, \mathrm{COCH}=), 6.62(2 \mathrm{H}, \mathrm{m}, 3,4-\mathrm{H} \text { of } \\
\text { pyrrolyl }), 6.87(2 \mathrm{H}, \mathrm{m}, 2,5-\mathrm{H} \text { of pyrrolyl }), 6.75(2 \mathrm{H}, \mathrm{d}, J=1.00 \mathrm{~Hz}, 3,5-\mathrm{H} \text { of } \\
\text { phenyl }), 7.33(2 \mathrm{H}, \mathrm{d}, J=1.00 \mathrm{~Hz}, 2,6-\mathrm{H} \text { of phenyl }), 7.82(1 \mathrm{H}, \mathrm{d}, J=3.1 \mathrm{~Hz},=\mathrm{CH}-) \text {, } \\
8.57-8.55,7.55-7.21(5 \mathrm{H}, \mathrm{m}, \text { phenyl-H })\end{array}$ \\
\hline $6 b$ & 464 & $1628(\mathrm{C}=\mathrm{O})$ & $\begin{array}{l}2.27\left(3 \mathrm{H}, \mathrm{s}, \mathrm{CH}_{3}\right), 3.06\left(6 \mathrm{H}, \mathrm{s}, \mathrm{N}\left(\mathrm{CH}_{3}\right)_{2}\right), 5.70(1 \mathrm{H}, \mathrm{d}, J=3.1 \mathrm{~Hz}, \mathrm{COCH}=), \\
6.59-6.50(2 \mathrm{H}, \mathrm{m}, 3,4-\mathrm{H} \text { of pyrrolyl }), 6.98-6.87(2 \mathrm{H}, \mathrm{m}, 2,5-\mathrm{H} \text { of pyrrolyl }), 6.70 \\
(2 \mathrm{H}, \mathrm{d}, J=1.0 \mathrm{~Hz}, 3,5-\mathrm{H} \text { of phenyl }), 7.25(2 \mathrm{H}, \mathrm{d}, J=1.5 \mathrm{~Hz}, 2,6-\mathrm{H} \text { of phenyl }), 7.75 \\
(1 \mathrm{H}, \mathrm{d}, J=3.1 \mathrm{~Hz},=\mathrm{CH}-), 8.57-8.54,7.51-7.50(5 \mathrm{H}, \mathrm{m}, \text { phenyl-H). }\end{array}$ \\
\hline $6 c$ & 435 & $1663(\mathrm{C}=\mathrm{O})$ & $\begin{array}{l}2.27\left(3 \mathrm{H}, \mathrm{s}, \mathrm{CH}_{3}\right), 2.39\left(3 \mathrm{H}, \mathrm{s}, \mathrm{CH}_{3}\right), 6.02(1 \mathrm{H}, \mathrm{d}, J=3.0 \mathrm{~Hz}, \mathrm{COCH}=), 6.61-6.51 \\
(2 \mathrm{H}, \mathrm{m}, 3,4-\mathrm{H} \text { of pyrrolyl }), 7.09-6.87(2 \mathrm{H}, \mathrm{m}, 2,5-\mathrm{H} \text { of pyrrolyl }), 7.79(1 \mathrm{H}, \mathrm{d}, \\
J=3.0 \mathrm{~Hz},=\mathrm{CH}-), 8.59-8.58,7.81-7.33(9 \mathrm{H}, \mathrm{m}, \text { phenyl-H). }\end{array}$ \\
\hline $6 d$ & 451 & $1668(\mathrm{C}=\mathrm{O})$ & $\begin{array}{l}2.33\left(3 \mathrm{H}, \mathrm{s}, \mathrm{CH}_{3}\right), 3.84\left(3 \mathrm{H}, \mathrm{s}, \mathrm{OCH}_{3}\right), 5.75(1 \mathrm{H}, \mathrm{d}, J=3.1 \mathrm{~Hz}, \mathrm{COCH}=), 6.60(2 \mathrm{H}, \\
\mathrm{t}, 3,4-\mathrm{H} \text { of pyrrolyl }), 6.87(2 \mathrm{H}, \mathrm{d}, J=1.0 \mathrm{~Hz}, 3,5-\mathrm{H} \text { of phenyl }), 6.99(2 \mathrm{H}, \mathrm{t}, 2,5-\mathrm{H} \text { of } \\
\text { pyrrolyl }), 7.28(2 \mathrm{H}, \mathrm{d}, J=1.0 \mathrm{~Hz}, 2,6-\mathrm{H} \text { of phenyl }), 7.76(1 \mathrm{H}, \mathrm{d}, J=3.0 \mathrm{~Hz},=\mathrm{CH}-) \text {, } \\
8.59-8.55,7.52-7.51(5 \mathrm{H}, \mathrm{m}, \text { phenyl-H). }\end{array}$ \\
\hline $6 e$ & 492 & $1628(\mathrm{C}=\mathrm{O})$ & $\begin{array}{l}1.21\left(6 \mathrm{H}, \mathrm{t}, J=1.4 \mathrm{~Hz}, \mathrm{CH}_{3}\right), 2.27\left(3 \mathrm{H}, \mathrm{s}, \mathrm{CH}_{3}\right), 3.41\left(4 \mathrm{H}, \mathrm{q}, J=1.4 \mathrm{~Hz}, \mathrm{CH}_{2}\right), 5.68 \\
(1 \mathrm{H}, \mathrm{d}, J=3.1 \mathrm{~Hz}, \mathrm{COCH}=), 6.59-6.49(4 \mathrm{H}, \mathrm{m}, 3,4-\mathrm{H} \text { of pyrrolyl and } 3,5-\mathrm{H} \text { of } \\
\text { phenyl), 6.98-6.87 }(2 \mathrm{H}, \mathrm{m}, 2,5-\mathrm{H} \text { of pyrrolyl }), 7.24(2 \mathrm{H}, \mathrm{d}, J=1.0 \mathrm{~Hz}, 2,6-\mathrm{H} \text { of } \\
\text { phenyl), } 7.74(1 \mathrm{H}, \mathrm{d}, J=3.0 \mathrm{~Hz},=\mathrm{CH}-), 8.56-8.53,7.50-7.49(5 \mathrm{H}, \mathrm{m}, \text { phenyl-H). }\end{array}$ \\
\hline $6 f$ & 497 & $1667(\mathrm{C}=\mathrm{O})$ & $\begin{array}{l}2.18\left(3 \mathrm{H}, \mathrm{s}, \mathrm{CH}_{3}\right), 5.75(1 \mathrm{H}, \mathrm{d}, J=3.0 \mathrm{~Hz}, \mathrm{COCH}=), 6.50(2 \mathrm{H}, \mathrm{t}, 3,4-\mathrm{H} \text { of pyrrolyl }) \text {, } \\
6.86(2 \mathrm{H}, \mathrm{t}, 2,5-\mathrm{H} \text { of pyrrolyl }), 8.65-8.54,7.63-7.38(15 \mathrm{H}, \mathrm{m},=\mathrm{CH}-\text { and phenyl-H). }\end{array}$ \\
\hline $6 \mathrm{~g}$ & 411 & $1667(\mathrm{C}=\mathrm{O})$ & $\begin{array}{l}2.28\left(3 \mathrm{H}, \mathrm{s}, \mathrm{CH}_{3}\right), 5.88(1 \mathrm{H}, \mathrm{d}, J=3.1 \mathrm{~Hz}, \mathrm{COCH}=), 6.59-6.48(3 \mathrm{H}, \mathrm{m}, 3,4-\mathrm{H} \text { of } \\
\text { pyrrolyl and } 4-\mathrm{H} \text { of furyl }), 6.87(2 \mathrm{H}, \mathrm{m}, 2,5-\mathrm{H} \text { of pyrrolyl }), 7.00(1 \mathrm{H}, \mathrm{d}, J=2.0 \mathrm{~Hz} \text {, } \\
3-\mathrm{H} \text { of furyl }), 8.15(1 \mathrm{H}, \mathrm{d}, J=3.0 \mathrm{~Hz},=\mathrm{CH}-), 8.63-8.54,7.58-7.48(6 \mathrm{H}, \mathrm{m}, 5-\mathrm{H} \text { of } \\
\text { furyl and phenyl-H). }\end{array}$ \\
\hline $6 h$ & 427 & $1641(\mathrm{C}=\mathrm{O})$ & $\begin{array}{l}2.11\left(3 \mathrm{H}, \mathrm{s}, \mathrm{CH}_{3}\right), 5.47(1 \mathrm{H}, \mathrm{d}, J=3.2 \mathrm{~Hz}, \mathrm{COCH}=), 6.63-6.39(3 \mathrm{H}, \mathrm{m}, 3,4-\mathrm{H} \text { of } \\
\text { pyrrolyl and } 4-\mathrm{H} \text { of thienyl }), 7.06-7.03(2 \mathrm{H}, \mathrm{m}, 2,5-\mathrm{H} \text { of pyrrolyl }), 7.13(1 \mathrm{H}, \mathrm{d} \text {, } \\
J=1.0 \mathrm{~Hz}, 3-\mathrm{H} \text { of thienyl }), 7.80(1 \mathrm{H}, \mathrm{d}, J=3.0 \mathrm{~Hz},=\mathrm{CH}-), 8.48-8.45,7.54-7.44 \\
(6 \mathrm{H}, \mathrm{m}, 5-\mathrm{H} \text { of thienyl and phenyl-H). }\end{array}$ \\
\hline $6 i$ & 545 & $1623(\mathrm{C}=\mathrm{O})$ & $\begin{array}{l}2.06\left(3 \mathrm{H}, \mathrm{s}, \mathrm{CH}_{3}\right), 5.79(1 \mathrm{H}, \mathrm{d}, J=3.1 \mathrm{~Hz}, \mathrm{COCH}=), 6.51(2 \mathrm{H}, \mathrm{m}, 3,4-\mathrm{H} \text { of } \\
\text { pyrrolyl }), 6.90(2 \mathrm{H}, \mathrm{m}, 2,5-\mathrm{H} \text { of pyrrolyl }), 8.62-8.42,8.32-8.05(15 \mathrm{H}, \mathrm{m},=\mathrm{CH}-\text {, } \\
\text { phenyl-H and pyrenyl-H). }\end{array}$ \\
\hline $6 j$ & 538 & $1633(\mathrm{C}=\mathrm{O})$ & $\begin{array}{l}1.77\left(3 \mathrm{H}, \mathrm{t}, J=1.2 \mathrm{~Hz}, \mathrm{CH}_{3}\right), 2.52\left(3 \mathrm{H}, \mathrm{s}, \mathrm{CH}_{3}\right), 4.03\left(2 \mathrm{H}, \mathrm{d}, J=1.0 \mathrm{~Hz}, \mathrm{CH}_{2}\right), 5.79 \\
(1 \mathrm{H}, \mathrm{d}, J=3.0 \mathrm{~Hz}, \mathrm{COCH}=), 6.51(2 \mathrm{H}, \mathrm{m}, 3,4-\mathrm{H} \text { of pyrrolyl }), 6.90(2 \mathrm{H}, \mathrm{m}, 2,5-\mathrm{H} \text { of } \\
\text { pyrrolyl }), 8.72-7.61,(13 \mathrm{H}, \mathrm{m},=\mathrm{CH}-\text {, phenyl-H and carbazolyl-H). }\end{array}$ \\
\hline $6 \mathrm{k}$ & 463 & $1643(\mathrm{C}=\mathrm{O})$ & $\begin{array}{l}2.10\left(3 \mathrm{H}, \mathrm{s}, \mathrm{CH}_{3}\right), 2.22\left(6 \mathrm{H}, \mathrm{s}, \mathrm{CH}_{3}\right), 2.28\left(3 \mathrm{H}, \mathrm{s}, \mathrm{CH}_{3}\right), 5.88(1 \mathrm{H}, \mathrm{d}, J=4.0 \mathrm{~Hz} \\
\mathrm{COCH}=), 6.51-6.45(2 \mathrm{H}, \mathrm{m}, 3,4-\mathrm{H} \text { of pyrrolyl }), 6.88-6.84(2 \mathrm{H}, \mathrm{m}, 2,5-\mathrm{H} \text { of } \\
\text { pyrrolyl }), 7.39(1 \mathrm{H}, \mathrm{d}, J=1.2 \mathrm{~Hz},=\mathrm{CH}-), 8.58-8.53,7.54-7.51(7 \mathrm{H}, \mathrm{m}, \text { phenyl-H). }\end{array}$ \\
\hline 61 & 478 & $\begin{array}{l}3324(\mathrm{NH}) \\
1622(\mathrm{C}=\mathrm{O})\end{array}$ & $\begin{array}{l}2.06\left(3 \mathrm{H}, \mathrm{s}, \mathrm{CH}_{3}\right), 2.16\left(3 \mathrm{H}, \mathrm{s}, \mathrm{COCH}_{3}\right), 5.78(1 \mathrm{H}, \mathrm{d}, J=3.0 \mathrm{~Hz}, \mathrm{COCH}=), 6.49 \\
(2 \mathrm{H}, \mathrm{m}, 3,4-\mathrm{H} \text { of pyrrolyl }), 6.97(2 \mathrm{H}, \mathrm{m}, 2,5-\mathrm{H} \text { of pyrrolyl }), 6.87(2 \mathrm{H}, \mathrm{d}, J=1.00 \mathrm{~Hz} \text {, } \\
\text { 3,5-H of phenyl), } 7.57(1 \mathrm{H}, \mathrm{d}, J=1.5 \mathrm{~Hz},=\mathrm{CH}-), 8.50-8.29,7.47-7.41(7 \mathrm{H}, \mathrm{m}, \\
\text { phenyl-H), } 8.29(1 \mathrm{H}, \mathrm{br}, \mathrm{NH}) .\end{array}$ \\
\hline $6 \mathrm{~m}$ & 521 & $1679(\mathrm{C}=\mathrm{O})$ & $\begin{array}{l}2.22\left(3 \mathrm{H}, \mathrm{s}, \mathrm{CH}_{3}\right), 6.13(1 \mathrm{H}, \mathrm{d}, J=3.0 \mathrm{~Hz}, \mathrm{COCH}=), 6.24(2 \mathrm{H}, \mathrm{m}, 3,4-\mathrm{H} \text { of } \\
\text { pyrrolyl }), 6.91(2 \mathrm{H}, \mathrm{m}, 2,5-\mathrm{H} \text { of pyrrolyl }), 8.93-7.99,7.54-7.26(15 \mathrm{H}, \mathrm{m},=\mathrm{CH}-\text {, } \\
\text { phenyl-H and anthracenyl-H). }\end{array}$ \\
\hline $6 n$ & 588 & $1631(\mathrm{C}=\mathrm{O})$ & $\begin{array}{l}2.30\left(3 \mathrm{H}, \mathrm{s}, \mathrm{CH}_{3}\right), 5.71(1 \mathrm{H}, \mathrm{d}, J=3.0 \mathrm{~Hz}, \mathrm{COCH}=), 6.55(2 \mathrm{H}, \mathrm{t}, 3,4-\mathrm{H} \text { of pyrrolyl }) \text {, } \\
6.98-6.94(4 \mathrm{H}, \mathrm{m}, 3,5-\mathrm{H} \text { of phenyl and } 2,5-\mathrm{H} \text { of pyrrolyl }), 7.74(1 \mathrm{H}, \mathrm{d}, J=3.0 \mathrm{~Hz} \text {, } \\
=\mathrm{CH}-), 8.59-8.57,7.53-7.13(17 \mathrm{H}, \mathrm{m} \text {, phenyl-H). }\end{array}$ \\
\hline
\end{tabular}

s: Singlet; d: doublet; t: triplet; m: multiplet; br: broad. 
$(60 \mathrm{~mL})$ was prepared with formulated dye and a dispersing agent (Diwatex 40,0.5 $\mathrm{g} \mathrm{L}^{-1}$ ) and adjusted to $\mathrm{pH} 4.0$. The polyester fabric $(2.0 \mathrm{~g})$ was immersed in the dyebath and dyed for $60 \mathrm{~min}$ at $130^{\circ} \mathrm{C}$. After dyeing, the dyed fabric was reduction cleared $\left(\mathrm{Na}_{2} \mathrm{~S}_{2} \mathrm{O}_{4} 2.0 \mathrm{~g} \mathrm{~L}^{-1}, \mathrm{NaOH} 2.0 \mathrm{~g} \mathrm{~L}^{-1}\right.$, soaping agent $2.0 \mathrm{~g} \mathrm{~L}^{-1}$ ) for $20 \mathrm{~min}$ at $75^{\circ} \mathrm{C}$.

2.6. Fastness Test. The light fastness was determined using standard procedures [41]. For sublimation fastness determinations, the dyed polyester fibers were stitched between two pieces of undyed polyester fibers (stain cloth) and treated at $200^{\circ} \mathrm{C}$ for $1 \mathrm{~min}$. Any staining on the undyed piece, change in tone, or loss in depth was assessed on 1 (poor) to 5 (very good) rating.

2.7. Colorimetric Analysis. The color parameters of the dyed polyester fabrics were measured using the Applied Color System, CS-5 chroma-sensor, model 502 using $\mathrm{D}_{65}$ source and ultraviolet radiation [42]. Each fabric sample was folded twice so as to realize a total of four thicknesses of fabric. The assessment of color-dyed fabrics was made in terms of tristimulus colorimetry [43]. The CIE attributes of lightness $\left(L^{*}\right)$, chroma $\left(C^{*}\right)$, and hue $\left(a^{*}\right.$ value represents the degree of redness (positive) and greenness (negative) and $b^{*}$ represents the degree of yellowness (positive) and blueness (negative)) were calculated in the present work.

\section{Results and Discussion}

3.1. Synthesis and Spectral Characteristics. All relevant reactions are depicted in Schemes 1 and 2. 4-Methyl-2-phenyl6-thioxo-1,6-dihydropyrimidine-5-carbonitrile $\mathbf{1}$, which is required as a starting material, was prepared in our previously reported [44]. Cyclization of thioxopyrimidine 1 with chloroacetone $\mathbf{2}$ in DMF in the presence of excess anhydrous potassium carbonate at room temperature gave the 1-(5-amino- 4-methyl-2-phenylthieno[2,3-d]pyrimidin6 -yl)ethanone 3 in good yields (Scheme 1). The possible mechanism for formation of compound 3 can be explained by the reaction pathway depicted in Scheme 1 . The IR spectrum of the compound 3 indicated the absence of the $\mathrm{C} \equiv \mathrm{N}$ and $\mathrm{C}=\mathrm{S}$ groups, and the amino group appears at $3424-3259 \mathrm{~cm}^{-1}$ in the form of two bands due to intramolecular association between the $5-\mathrm{NH}_{2}$ and $6-\mathrm{COCH}_{3}$ groups of compound 3 and the characteristic absorption band at $1663 \mathrm{~cm}^{-1}$ for the carbonyl group $(\mathrm{C}=\mathrm{O})$. In addition, the ${ }^{1} \mathrm{H}$ NMR spectra $\left(\mathrm{CDCl}_{3}\right)$ of compound 3 showing a singlet at $\delta 2.47(3 \mathrm{H}, \mathrm{s})$ assigned for the acetyl group, a broad singlet at $3.76(2 \mathrm{H}, \mathrm{br})$ assigned to the $\mathrm{NH}_{2}$ protons, and a multiplet at $\delta 8.58-7.55$ $(5 \mathrm{H}, \mathrm{m})$ assigned to the phenyl protons were also confirmed by the mass spectra $m / z 283\left(\mathrm{M}^{+}, 100\right)$.

Moreover, treatment of compound 3 with 2,5dimethoxytetrahydrofuran in glacial acetic acid produced the 1-[4-methyl-2-phenyl-5-(1H-pyrrol-1-yl)thieno[2,3-d]pyrimidin-6-yl] ethanone 4 (Scheme 1). The IR spectrum of the compound 4 indicates the absence of the $\mathrm{NH}_{2}$ group. The ${ }^{1} \mathrm{H}$ NMR spectra $\left(\mathrm{CDCl}_{3}\right)$ of the compound $\mathbf{4}$ show a singlet at $\delta 2.09(3 \mathrm{H}, \mathrm{s})$ assigned for the acetyl group and two triplets at $\delta 6.50(2 \mathrm{H}, \mathrm{t})$ and $6.87(2 \mathrm{H}, \mathrm{t})$, which were readily assigned to the hydrogen attached at $\mathrm{C}_{3}, \mathrm{C}_{4}$ and $\mathrm{C}_{2}$, and $\mathrm{C}_{5}$ of the pyrrolyl ring, respectively. On the other hand, the 3-aryl-1-[4-methyl-2-phenyl-5-(1H-pyrrol-1-yl)thieno[2,3d]pyrimidin-6-yl]prop-2-en-1-one chalcone dyes $\mathbf{6 a - n}$ were obtained in good yields (84-98\%) based on Claisen-Schmidt condensation of compound $\mathbf{4}$ with appropriate aldehydes $\mathbf{5 a}-\mathbf{n}$ (Scheme 2). The formation of compounds $\mathbf{6 a}-\mathbf{n}$ can be explained by the reaction pathway depicted in Scheme 2. The mechanism [44] involves base $\left(\mathrm{OH}^{-}\right)$removes a $\mathrm{C}-\mathrm{H}$ proton of $\mathrm{CH}_{3} \mathrm{CO}$ group in compound 4 to give carbanion $\mathbf{4}^{\prime}$, which then adds to $\mathrm{C}=\mathrm{O}$ group in aldehydes 5 , followed then undergoes condensation via dehydration affording the final products $\mathbf{6} \mathbf{a}-\mathbf{n}$. The structures of dyes $\mathbf{6} \mathbf{a}-\mathbf{n}$ were established by examining spectral data and elemental analysis. The IR spectrum of dyes $\mathbf{6 a}-\mathbf{n}$ indicates the characteristic absorption bands at $1679-1622 \mathrm{~cm}^{-1}$ for the $\mathrm{C}=\mathrm{O}$ group. Physical and spectral data of dyes $\mathbf{6 a}-\mathbf{n}$ are given in Tables 1 and 2 .

3.2. Absorption Spectral Characteristics. The absorption maxima $\left(\lambda_{\max }\right)$ of the dyes $\mathbf{6 a}-\mathbf{n}$ were measured in DMF solution and are listed in Table 3 . The absorption maxima of the dyes $\mathbf{6 a}-\mathbf{n}$ ranged from 412 to $488 \mathrm{~nm}$, with dye $\mathbf{6 e}$ showing the highest $\lambda_{\max }(488 \mathrm{~nm})$ and $\mathbf{6 a}$ the lowest $(412 \mathrm{~nm})$. Color shifts are in accord with variations resultant from changes in substituents in these dyes. As seen from Table 3 , structural modification occurs only in one terminal moiety, where a p-chlorophenyl donor 6 a was replaced by a dialkyl(aryl)aminophenyl or heteroaryl or polycyclic groups. Such a modification could be expected to result in notable changes in the $\pi$-conjugated and red shifts in the absorption spectra. The $\lambda_{\max }$ of dyes $\mathbf{6 a}-\mathbf{n}$ is related to intramolecular charge transfer (ICT) chromophoric system in which these molecules consist of a typical A- $\pi$-D structure, where 6carbonyl-pyrrolythieno[2,3-d]pyrimidinyl, vinyl, and substituent moieties (R) are employed as acceptor (A), $\pi$ conjugated center $(\pi)$, and donor (D) moieties, respectively. The absorption maxima are mainly dominated by the nature of the excited state $\pi$-electron system. As well known, a strong electron donor could help to stabilize the charge-separated excited state of the molecule; the red-shift could be explained by the electron-donating strength of donor group [35, 46].

Compound 6a, as a standard, absorbed at $412 \mathrm{~nm}$ and substituent effects on the absorption maxima were evaluated compared with this value. As is apparent in Table 3, introduction of electron-donating substituents into the 6-carbonyl-pyrroly-thieno[2,3-d]pyrimidinylbased chromophore produces a significant bathochromic shifts of the absorption maxima. The differences of these values are shown by $\Delta \lambda_{\max }$. As a result, the dyes 6b-n were bathochromic shift of $11-76 \mathrm{~nm}$. It can be seen from Table 3 that dyes $\mathbf{6 b}, \mathbf{6 e}, \mathbf{6 l}$, and $\mathbf{6 n}$ selected in this case produced bathochromic shifts of 41 to $76 \mathrm{~nm}$ caused by introduction of the stronger electrondonating substituents (dialkyl(aryl)aminophenyl) into 6-carbonyl-pyrrolythieno[2,3-d]pyrimidinyl-based chromophore at which there is an electron density decrease 


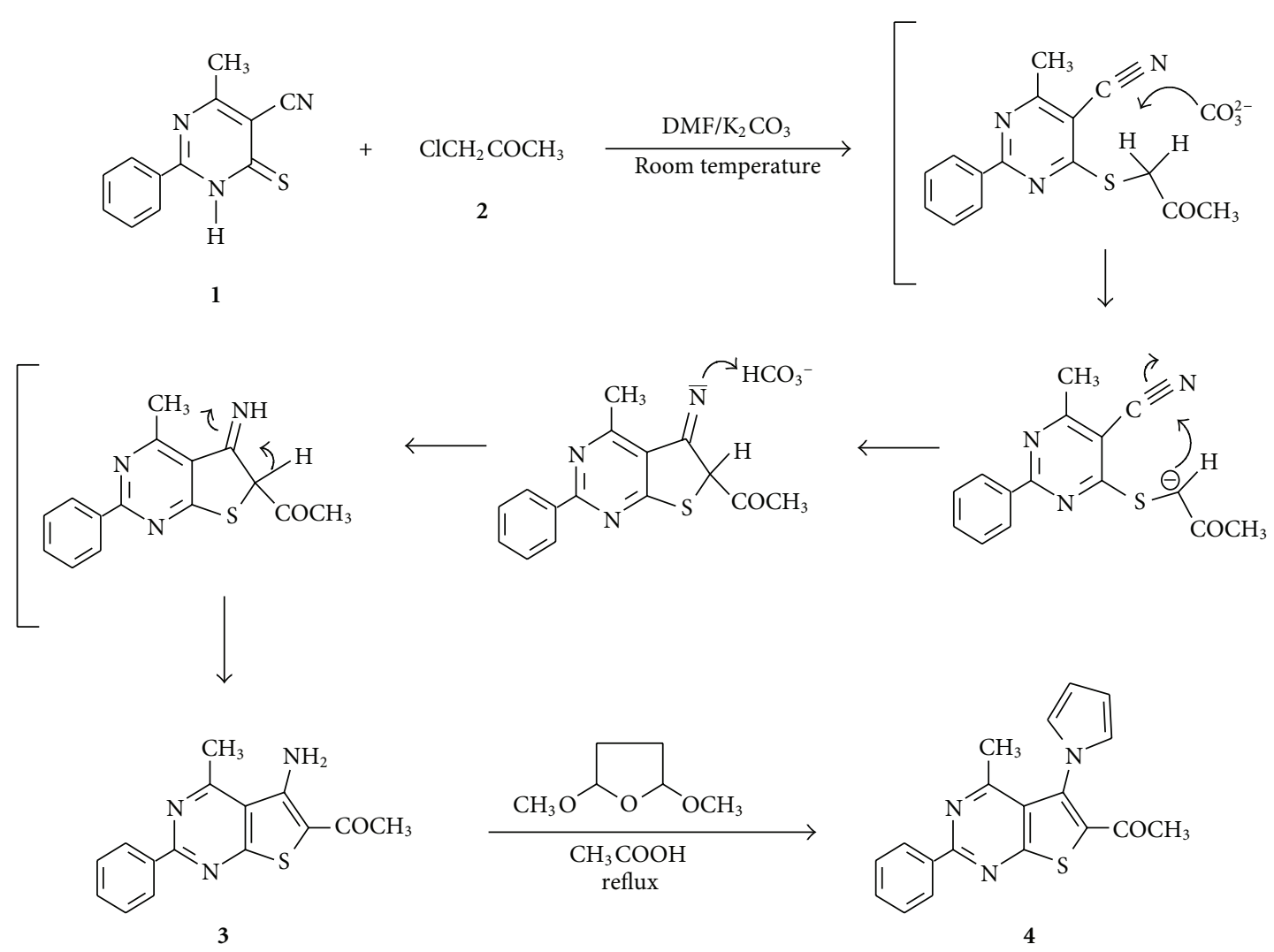

SCHEme 1: Synthesis of compound 4.

that should produce a bathochromic shift of $\lambda_{\max }$ [46]. In general, with respect to the substituents $\mathrm{R}$ of dyes $\mathbf{6 b}, \mathbf{6 e}, \mathbf{6 1}$, and $\mathbf{6 n}$, the dyes were bathochromically shifted in the following order: diethylaminophenyl (6e) $\left(\Delta \lambda_{\max } 76 \mathrm{~nm}\right)>$ diphenylaminophenyl (6n) $\left(\Delta \lambda_{\max }\right.$ $58 \mathrm{~nm})>$ dimethylaminophenyl (6b) $\left(\Delta \lambda_{\max } \quad 43 \mathrm{~nm}\right)>4$ acetamidophenyl (61) $\left(\Delta \lambda_{\max } 41 \mathrm{~nm}\right)$. Furthermore, the spectroscopic data also demonstrate that the dye $6 \mathrm{e}\left(\lambda_{\max }\right.$ $488 \mathrm{~nm}$ ) containing the diethylaminophenyl group showed a largest bathochromic shift of $76 \mathrm{~nm}$.

On the other hand, $\lambda_{\max }$ value in the case of selected dyes $\mathbf{6 c}, \mathbf{6 f}, \mathbf{6 i}, \mathbf{6 j}, \mathbf{6 k}$, and $\mathbf{6 m}$ indicates that replacement of the p-chlorophenyl group of dye $\mathbf{6 a}$ for appropriate heteroaryl or polycyclic substituents, such as tolyl (6c), biphenylyl (6f), pyrenyl (6i), carbazolyl (6j), 2,4,6-trimethylphenyl (6k), and anthryl $(6 \mathrm{~m})$, leads to a significant bathochromic shift of 11 to $69 \mathrm{~nm}$. The differences of these values are shown by $\Delta \lambda_{\max }$. For instance, dye $\mathbf{6 a}$ was absorbed at $412 \mathrm{~nm}$, with increasing donor ability from the p-chlorophenyl (6a) to the carbazolyl $(\mathbf{6 j})$, pyrenyl $(\mathbf{6 i})$, and anthryl $(\mathbf{6 m})$; their $\Delta \lambda_{\max }$ values show large bathochromic shifts to $442 \mathrm{~nm}$ $\left(\Delta \lambda_{\max }=30 \mathrm{~nm}\right), 478 \mathrm{~nm}\left(\Delta \lambda_{\max }=66 \mathrm{~nm}\right)$, and $481 \mathrm{~nm}$ $\left(\Delta \lambda_{\max }=69 \mathrm{~nm}\right)$, respectively. In general, with respect to the substituents $R$ of dyes $\mathbf{6 c}, \mathbf{6 f}, \mathbf{6 i}, \mathbf{6 j}, \mathbf{6 k}$, and $\mathbf{6 m}$, the dyes were bathochromically shifted in the following order: anthryl (6m) $\left(\Delta \lambda_{\max } 69 \mathrm{~nm}\right)>$ pyrenyl $(6 \mathbf{i})\left(\Delta \lambda_{\max } 66 \mathrm{~nm}\right)>$ biphenylyl (6f) $\left(\Delta \lambda_{\max } 44 \mathrm{~nm}\right)>$ carbazolyl (6j) $\left(\Delta \lambda_{\max } 30 \mathrm{~nm}\right)>2,4,6-$ trimethylphenyl (6k) $\left(\Delta \lambda_{\max } 28 \mathrm{~nm}\right)>$ tolyl $(6 \mathbf{c}) \quad\left(\Delta \lambda_{\max }\right.$
$11 \mathrm{~nm})$. Moreover, the spectroscopic data also demonstrate that the dye $\mathbf{6 g}\left(\lambda_{\max } 442 \mathrm{~nm}\right)$ containing the furyl moiety shows a bathochromic shift of $18 \mathrm{~nm}$ in comparison with the dye $6 \mathbf{h}\left(\lambda_{\max } 424 \mathrm{~nm}\right)$ containing the thienyl moiety.

In brief, dyes derived from dialkyl(arkyl)aminophenyl substituents exhibited significantly larger bathochromic shift compared with those derived from heteroaryl or polycyclic substituents. Furthermore, it is well known that molar extinction coefficients $\varepsilon$ values reflect the molecular planarity and enlargement of $\pi$-conjugation. The dyes $\mathbf{6 c}, \mathbf{6 f}, \mathbf{6 k}$, and $6 \mathbf{m}$ have bigger $\varepsilon$ values than those of other dyes which indicates that dyes $6 \mathrm{c}, \mathbf{6 f}, \mathbf{6 k}$, and $\mathbf{6 m}$ have much more planar and rigid $\pi$-conjugation system than that of other dyes [47].

3.3. Dyeing and Fastness Properties. For imparting greenishyellow to orange hues, the dyes $\mathbf{6 a}-\mathbf{n}$ were applied to polyester fiber at $1 \%$ shade by high-temperature-pressure techniques. The fastness properties of the dyes are shown in Table 3. Table 3 shows that the light fastness of these dyes varied from 1-5; thus the dyes $\mathbf{6 b}, \mathbf{6 e}, \mathbf{6} \mathbf{g}, \mathbf{6 j}, \mathbf{6 k}$, and $\mathbf{6} \mathbf{l}$ had poor light fastness (1-2), dyes $\mathbf{6 c}, \mathbf{6 d}, \mathbf{6 f}, \mathbf{6 h}, \mathbf{6 i}$, and $\mathbf{6 m}$ had fair light fastness (3-4), and dyes $\mathbf{6 a}$ and $\mathbf{6 n}$ had good light fastness (4-5). In general, the dyes in the range of 3-5 show good sublimation fastness properties on polyester fibers.

3.4. Colorimetric Assessment. Three important attributes of color that must be considered in the development of new colorants are lightness, chroma, and hue. These attributes can 


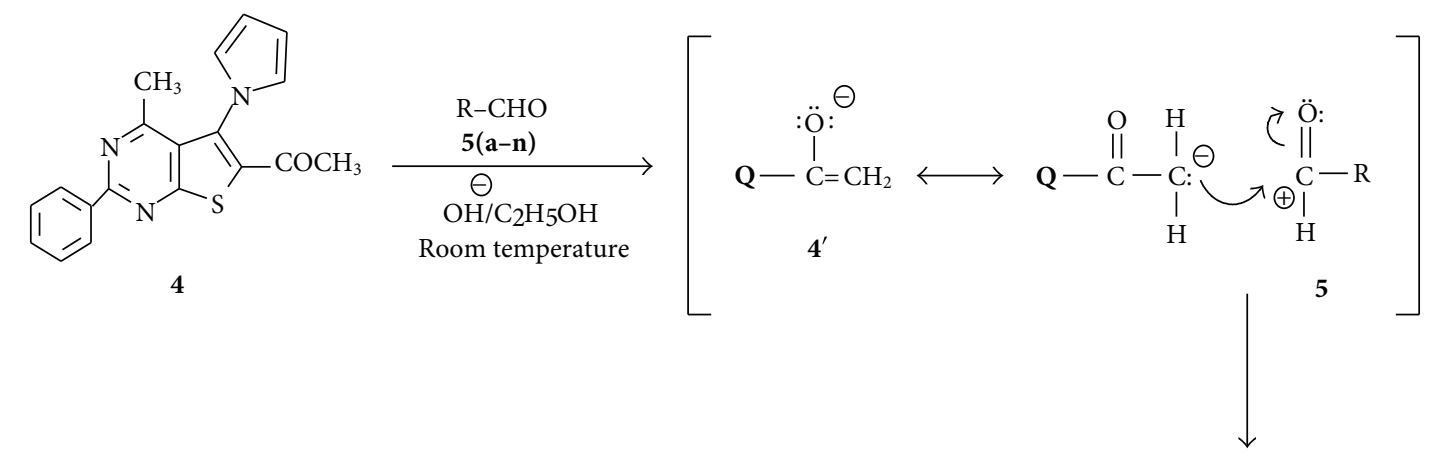<smiles>Cc1nc(-c2ccccc2)nc2scc(-n3cccc3)c12</smiles>

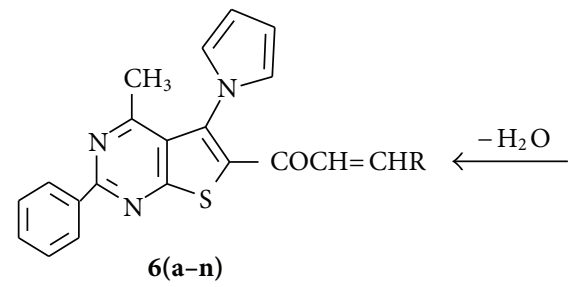<smiles>[R]C(O)C(C)C(C)C(=O)O</smiles>

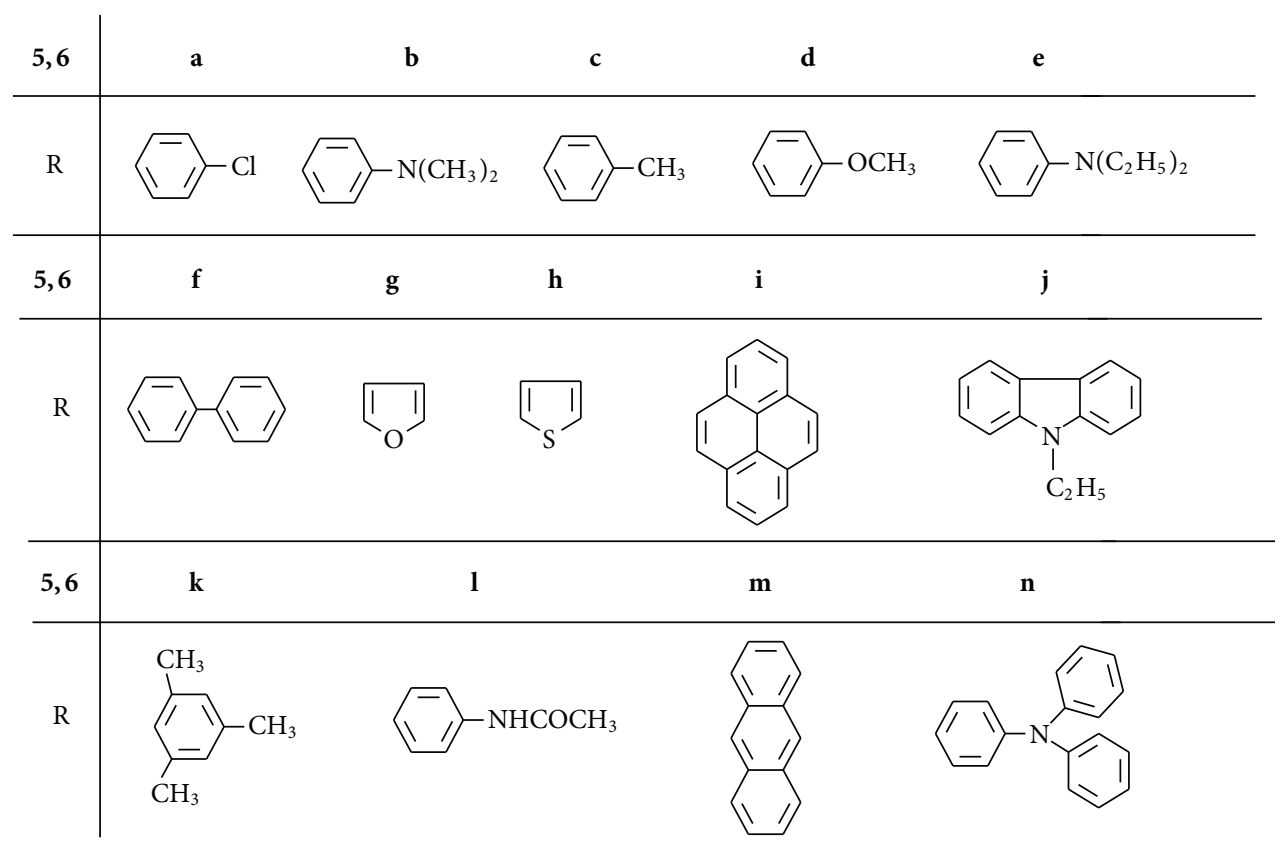

SCHeme 2: Synthesis of chalcone dyes $\mathbf{6}(\mathbf{a}-\mathbf{n})$.

be determined by colorimetric assessment using the prototype dye. The CIE attributes of lightness $\left(L^{*}\right)$, chroma $\left(C^{*}\right)$, and hue $\left(a^{*}=\right.$ redness/greenness; $b^{*}=$ yellowness/blueness $)$ were calaulated in the present work. The values of the CIE coordinate $\left(L^{*}, a^{*}, b^{*}, h^{\circ}\right.$, and $\left.C^{*}\right)$ are listed in Table 4. According to Richter [48] and McLaren et al. [49] the position of the color is distributed in the red-green area with hue angle $h^{\circ} 33.07-116.83^{\circ}$ and radial chroma $C^{*}$ of length $8.35-48.08$. Figure 1 shows a graph of CIE coordinates $a^{*}$ versus $b^{*}$ for selected dyes $\mathbf{6} \mathbf{b}, \mathbf{6 e}, \mathbf{6}$, and $\mathbf{6 n}$ (an increasing $a^{*}$ value represents an increase in redness, while a decrease in $a^{*}$ represents a green hue shift). Dyes $\mathbf{6 1}$ and $\mathbf{6 n}$ provided a reference point for the color attributes of each dye, since $6 \mathbf{l}$ is a yellow and $\mathbf{6 n}$ is a strong orange. The dye based on dimethylaminophenyl (6b) was yellow-orange, and thus the $a^{*} b^{*}$ graph shows the dye to be bathochromic compared with $\mathbf{6 l}$ and hypsochromic relative to $\mathbf{6 n}$. Apart from $\mathbf{6 e}$ and $\mathbf{6 n}$, dyes displayed similar hues both to each other and to 6l. Hence, the presence of stronger electron-donating substituents in the 6-carbonyl-pyrrolythieno[2,3-d]pyrimidinyl-based chromophore linkage produced the desired colorimetric effect.

Furthermore, Figures 2 and 3 show a graph of CIE $C^{*}$ versus $L^{*}$ for selected dyes $(\mathbf{6 b}, \mathbf{6 e}, \mathbf{6 l}$ and $\mathbf{6 n})$ and $(\mathbf{6 a}, \mathbf{6 c}$, 6d, 6f-6k, and 6m), respectively. In general, dyes derived from dialkyl(arkyl)aminophenyl substituents exhibited significantly higher chroma compared with those derived from 
TABLE 3: Absorption spectra and dyeing properties of 6-(3-substituted-acryloyl)-5-(1-pyrrolyl)-4-methyl-2-phenyl-thieno[2,3- $d$ ]pyrimidine derivatives $\mathbf{6 a}-\mathbf{n}$.

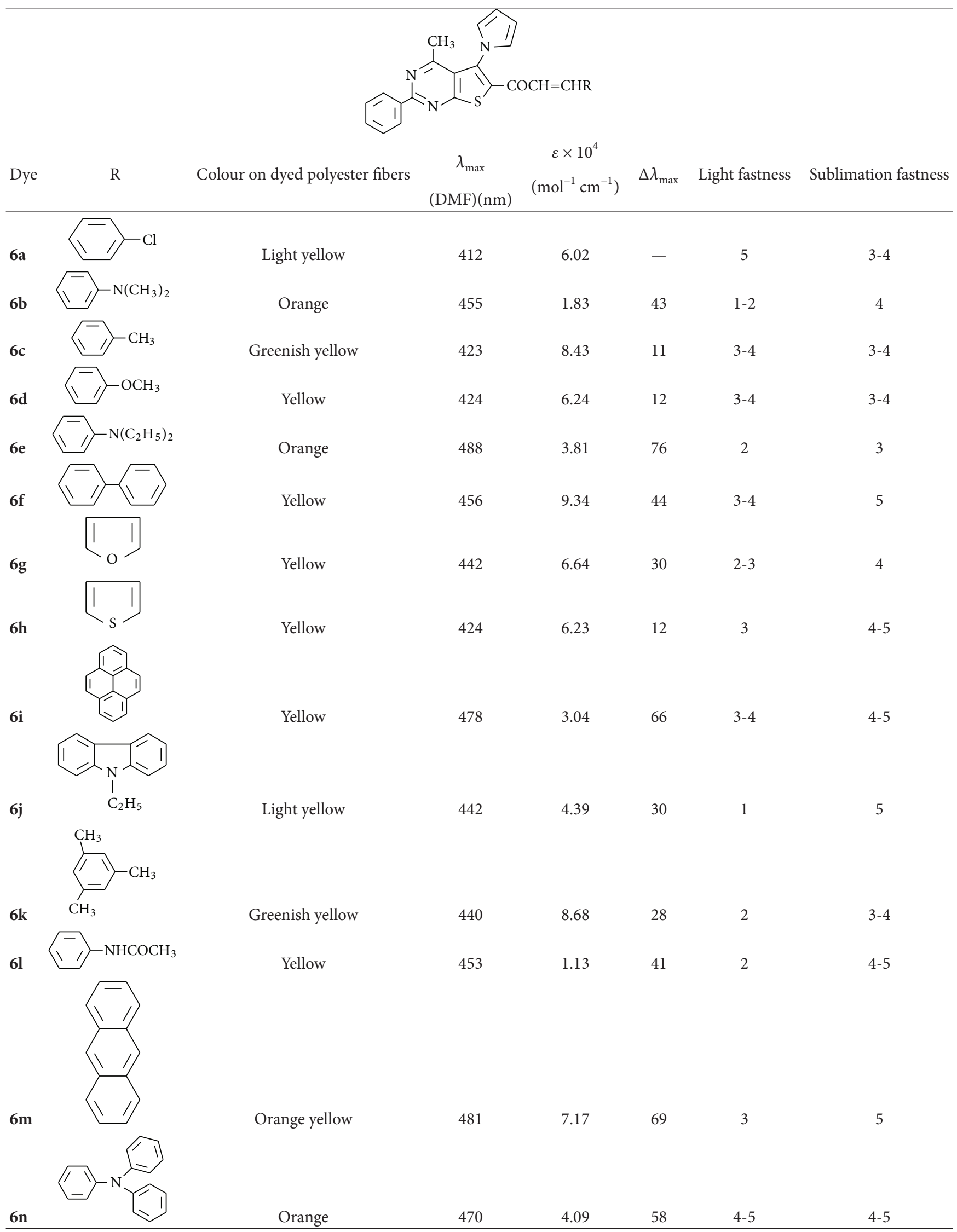


TABLE 4: CIE of dyes $\mathbf{6 a - n}$ on polyester.

\begin{tabular}{|c|c|c|c|c|c|c|}
\hline Dye & $L^{*}$ & $a^{*}$ & $b^{*}$ & $C^{*}$ & $h^{o}$ & $\mathrm{~K} / \mathrm{S}$ \\
\hline $6 a$ & 88.40 & 0.09 & 9.52 & 9.52 & 90.56 & 0.1789 \\
\hline $6 b$ & 91.32 & 17.34 & 37.98 & 41.76 & 65.46 & 0.9125 \\
\hline $6 c$ & 84.29 & -3.77 & 7.45 & 8.35 & 116.83 & 0.3417 \\
\hline $6 d$ & 91.06 & -6.12 & 21.90 & 22.74 & 105.60 & 0.4236 \\
\hline $6 e$ & 85.84 & 33.35 & 34.63 & 25.55 & 46.06 & 1.3319 \\
\hline $6 f$ & 89.61 & -0.79 & 15.38 & 15.40 & 92.96 & 0.2368 \\
\hline $6 g$ & 73.24 & 6.04 & 15.97 & 17.07 & 69.27 & 0.7793 \\
\hline $6 \mathrm{~h}$ & 88.41 & -3.80 & 24.22 & 24.52 & 98.92 & 0.5565 \\
\hline $6 i$ & 89.52 & -0.10 & 11.27 & 11.27 & 90.50 & 0.3050 \\
\hline $6 j$ & 90.60 & -6.69 & 33.96 & 34.61 & 101.14 & 0.8942 \\
\hline $6 k$ & 82.53 & -2.94 & 12.51 & 12.85 & 103.22 & 0.6437 \\
\hline 61 & 85.06 & 5.34 & 24.99 & 48.08 & 46.08 & 0.4600 \\
\hline $6 m$ & 83.41 & 9.27 & 20.99 & 22.95 & 66.18 & 0.3820 \\
\hline $6 n$ & 76.37 & 35.23 & 22.94 & 42.04 & 33.07 & 0.5334 \\
\hline
\end{tabular}

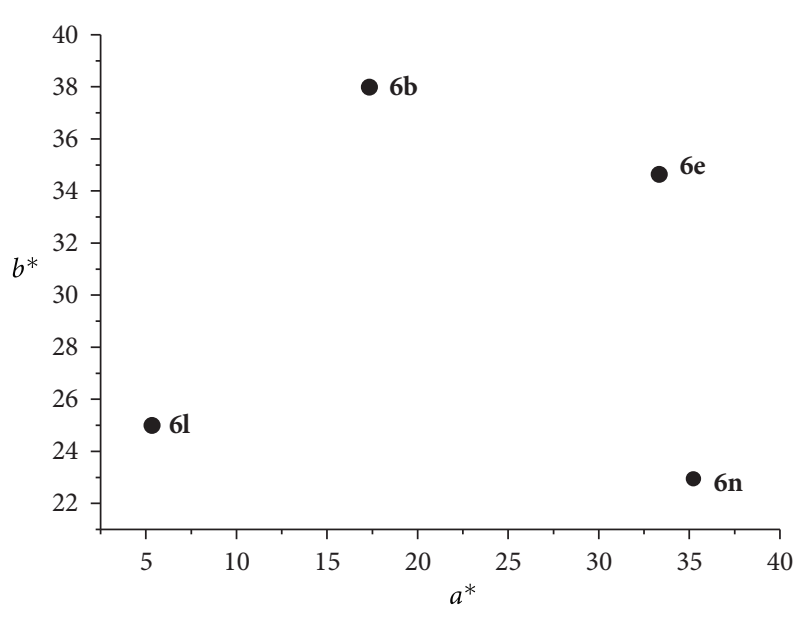

FIGURE 1: Graph of CIE $a^{*}$ versus $b^{*}$ for selected dyes.

heteroaryl or polychlic substituents. Figure 2 shows that the dyes $\mathbf{6 b}, \mathbf{6 e}$, and $\mathbf{6 l}$ were lighter than $\mathbf{6 n}$. Similar results are observed in Figure 3; the lightness of $\mathbf{6 a}, \mathbf{6 c}, \mathbf{6 d}, \mathbf{6 f}, \mathbf{6 h}-\mathbf{k}$, and $\mathbf{6 m}$ were all high except for dye $\mathbf{6 g}$.

On the other hand, Figure 4 shows a graph of CIE coordinates $a^{*}$ versus $b^{*}$ for selected dyes $\mathbf{6 a}, \mathbf{6 c}, \mathbf{6 d}, \mathbf{6} \mathbf{f}-\mathbf{6 k}$ and $6 \mathrm{~m}$. As the $b^{*}$ scale represents yellowness (increasing $b^{*}$ value) versus blueness (decreasing $b^{*}$ value), it is evident that most of the new dyes were significantly yellower than $\mathbf{6 c}$. The dye $\mathbf{6 f}$ based on biphenylyl possessed approximately the same yellowness but was redder than dye $\mathbf{6 j}$. However, the dyes $\mathbf{6 c}$, $\mathbf{6 d}, \mathbf{6 h}$, and $\mathbf{6 k}$ were green hue shift relative to the dye $\mathbf{6 f}$, although not as green as $\mathbf{6 j}$, and were similar in hue to $\mathbf{6 d}$. Also, the dyes based on p-chlorophenyl (6a) and tolyl (6c) were bluer than biphenylyl (6f) and 2,4,6-trimethylphenyl (6k). In the case of $\mathbf{6 a}$ and $\mathbf{6 c}$, the hypsochromic shift due to the presence of weak electron-donating substituents in the 6-carbonyl-pyrrolythieno[2,3-d]pyrimidinyl-based chromophore linkage is significant. In addition, dyes based on

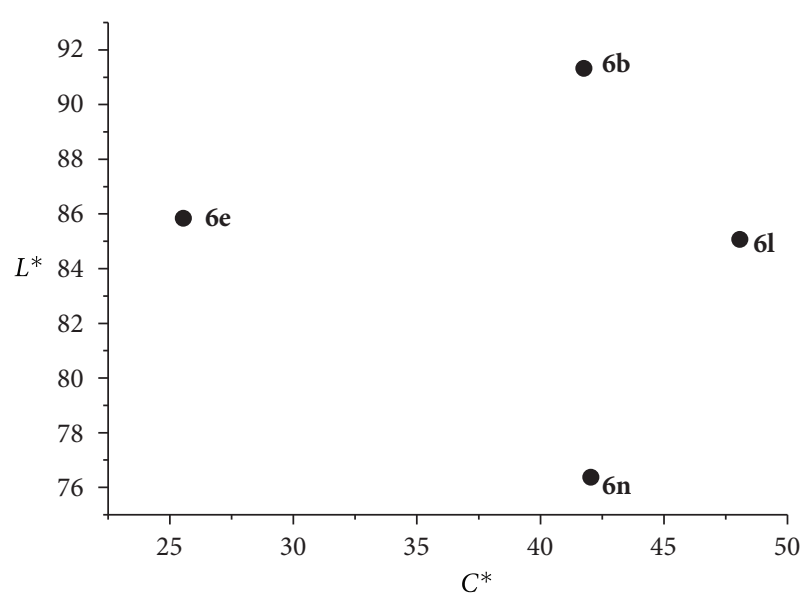

FIGURE 2: Graph of CIE $C^{*}$ versus $L^{*}$ for selected dyes.

furyl $(6 \mathrm{~g})$ and anthryl $(6 \mathrm{~m})$ were bathochromic relative to when p-chlorophenyl (6a) was employed.

\section{Conclusions}

Fourteen novel heterocyclic chalcone derivatives containing a thieno-[2,3- $d]$ pyrimidine-based chromophore were obtained from thioxopyrimidine 1 . The chalcone derivatives were applied to polyester fibers as disperse dyes for creating hues ranging from greenish-yellow to orange. The substituent effect in DMF solution was also discussed. The results indicate that the novel chalcone dyes derived from dialkyl(arkyl)aminophenyl substituents exhibited significantly larger bathochromic shift compared with those derived from heteroaryl or polycyclic substituents. On the other hand, color shifts are in accord with variations resultant from changes in substituents in these dyes. In general, the presence of dialkyl(aryl)aminophenyl substituents in the thieno[2,3-d]pyrimidinyl-based chromophore linkage produced the red hue shift, while the heteroaryl or polychlic 


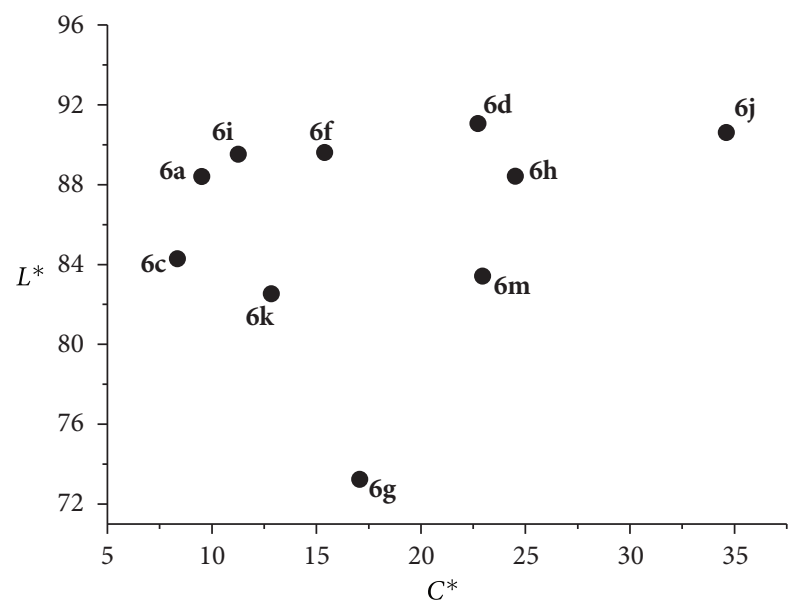

Figure 3: Graph of CIE $C^{*}$ versus $L^{*}$ for selected dyes.

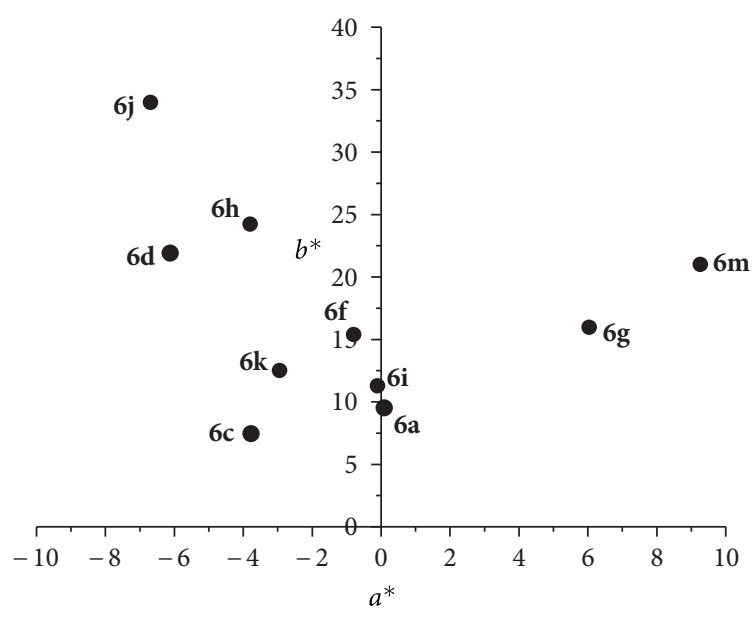

FIgURE 4: Graph of CIE $a^{*}$ versus $b^{*}$ for selected dyes.

substituents produced the green hue shift. In addition, these dyes showed good sublimation fastness and poor- to goodlight fastness on polyester fibers.

\section{Acknowledgments}

The authors are grateful to the high valued instrument Center of National Taiwan Normal University for measuring the data of spectroscopy. They also want to thank National Science Council of Taiwan (NSC 97-2113-M-253-001) for their financial support.

\section{References}

[1] M. A. El-Sherbeny, M. B. El-Ashmawy, H. I. El-Subbagh, A. A. El-Emam, and F. A. Badria, "Synthesis, antimicrobial and antiviral evaluation of certain thienopyrimidine derivatives," European Journal of Medicinal Chemistry, vol. 30, no. 5, pp. 445-449, 1995.

[2] A. M. A. Hameed, "Synthesis of new 1, 2, 4-oxadiazolidin-5ylthiophenes and thienopyrimidine derivatives by aza-Wittig reaction using a thienyl carbodiimide," Chinese Chemical Letters, vol. 23, no. 4, pp. 411-414, 2012.

[3] A. Panico, V. Cardile, B. Gentile, and A. Santagati, "Thienopyrimidine derivatives prevent cartilage destruction in articular disease," Il Farmaco, vol. 56, no. 12, pp. 959-964, 2001.

[4] H. N. Hafez, H. A. R. Hussein, and A. R. B. A. ElGazzar, "Synthesis of substituted thieno[2,3-d]pyrimidine-2,4dithiones and their $S$-glycoside analogues as potential antiviral and antibacterial agents," European Journal of Medicinal Chemistry, vol. 45, no. 9, pp. 4026-4034, 2010.

[5] V. Alagarsamy, S. Meena, K. V. Ramseshu et al., "Synthesis, analgesic, anti-inflammatory, ulcerogenic index and antibacterial activities of novel 2-methylthio-3-substituted5,6,7,8-tetrahydrobenzo (b) thieno[2,3-d]pyrimidin-4(3H)ones," European Journal of Medicinal Chemistry, vol. 41, no. 11, pp. 1293-1300, 2006.

[6] A. M. Almerico, P. Diana, P. Barraja et al., "Glycosidopyrroles Part 1. Acyclic derivatives: 1-(2-hydroxyethoxy) methylpyrroles as potential anti-viral agents," Il Farmaco, vol. 53, no. 1, pp. 33-40, 1998.

[7] E. A. Meade, M. Sznaidman, G. T. Pollard, L. M. Beauchamp, and J. L. Howard, "Anxiolytic activity of analogues of 4benzylamino-2-methyl-7H- pyrrolo[2,3-d]pyrimidines," European Journal of Medicinal Chemistry, vol. 33, no. 5, pp. 363-374, 1998.

[8] L. W. Hsin, X. Tian, E. L. Webster et al., "CRHR1 Receptor binding and lipophilicity of pyrrolopyrimidines, potential nonpeptide corticotropin-releasing hormone type 1 receptor antagonists," Bioorganic \& Medicinal Chemistry, vol. 10, no. 1, pp. 175-183, 2002.

[9] I. Recchia, N. Rucci, C. Festuccia et al., "Pyrrolopyrimidine cSrc inhibitors reduce growth, adhesion, motility and invasion of prostate cancer cells in vitro," European Journal of Cancer, vol. 39, no. 13, pp. 1927-1935, 2003.

[10] V. Lather and A. K. Madan, "Topological model for the prediction of MRP1 inhibitory activity of pyrrolopyrimidines and templates derived from pyrrolopyrimidine," Bioorganic \& Medicinal Chemistry Letters, vol. 15, no. 22, pp. 4967-4972, 2005.

[11] D. N. Dhar, The Chemistry of Chalcones and Realated Compounds, Wiley, New York, NY, USA, 1981.

[12] Y. M. Lin, Y. Zhou, M. T. Flavin, L. M. Zhou, W. Nie, and F. C. Chen, "Chalcones and flavonoids as anti-tuberculosis agents," Bioorganic \& Medicinal Chemistry, vol. 10, no. 8, pp. 2795-2802, 2002.

[13] X. L. Liu, H. W. Tee, and M. L. Go, "Functionalized chalcones as selective inhibitors of P-glycoprotein and breast cancer resistance protein," Bioorganic \& Medicinal Chemistry, vol. 16, no. 1, pp. 171-180, 2008.

[14] J. Rojas, J. N. Domínguez, J. E. Charris, G. Lobo, M. Payá, and M. L. Ferrándiz, "Synthesis and inhibitory activity of dimethylamino-chalcone derivatives on the induction of nitric oxide synthase," European Journal of Medicinal Chemistry, vol. 37, no. 8, pp. 699-705, 2002.

[15] Z. Nowakowska, "A review of anti-infective and antiinflammatory chalcones," European Journal of Medicinal Chemistry, vol. 42, no. 2, pp. 125-137, 2007.

[16] S. Vogel, M. Barbic, G. Jürgenliemk, and J. Heilmann, "Synthesis, cytotoxicity, anti-oxidative and anti-inflammatory activity of chalcones and influence of A-ring modifications on the pharmacological effect," European Journal of Medicinal Chemistry, vol. 45, no. 6, pp. 2206-2213, 2010. 
[17] J. Y. Jaung, M. Matsuoka, and K. Fukunishi, "Dicyanopyrazine studies. Part V: syntheses and characteristics of chalcone analogues of dicyanopyrazine," Dyes and Pigments, vol. 40, no. 1, pp. 11-20, 1999.

[18] Y. F. Sun and Y. P. Cui, "The synthesis, characterization and properties of coumarin-based chromophores containing a chalcone moiety," Dyes and Pigments, vol. 78, no. 1, pp. 65-76, 2008.

[19] A. John Kiran, A. Mithun, B. Shivarama Holla, H. D. Shashikala, G. Umesh, and K. Chandrasekharan, "Nonlinear optical studies of 1-3-diaryl-propenones containing 4-methylthiophenyl moieties," Optics Communications, vol. 269, no. 1, pp. 235-240, 2007.

[20] M. Zhang, M. Y. Li, Q. Zhao et al., "Novel Y-type two-photon active fluorophore: synthesis and application in fluorescent sensor for cysteine and homocysteine," Tetrahedron Letters, vol. 48, no. 13, pp. 2329-2333, 2007.

[21] L. Porrès, O. Mongin, and M. Blanchard-Desce, "Synthesis, fluorescence and two-photon absorption properties of multichromophoric boron-dipyrromethene fluorophores for twophoton-excited fluorescence applications," Tetrahedron Letters, vol. 47, no. 12, pp. 1913-1917, 2006.

[22] X. M. Wang, P. Yang, G. B. Xu, W. L. Jiang, and T. S. Yang, "Two-photon absorption and two-photon excited fluorescence of triphenylamine-based multibranched chromophores," Synthetic Metals, vol. 155, no. 3, pp. 464-473, 2005.

[23] Z. Z. Huang, X. M. Wang, B. Li et al., "Two-photon absorption of new multibranched chromophores based on bis(diphenylamino)stilbene," Optical Materials, vol. 29, no. 8, pp. 1084-1090, 2007.

[24] D. M. Song, K. H. Jung, J. H. Moon, and D. M. Shin, "Photochemistry of chalcone and the application of chalconederivatives in photo-alignment layer of liquid crystal display," Optical Materials, vol. 21, no. 1-3, pp. 667-671, 2003.

[25] Z. D. Yang, J. K. Feng, and A. M. Ren, “Theoretical study of one-photon and two-photon absorption properties for 2,1,3benzothiadiazole-based red-fluorescent dyes," Journal of Molecular Structure, vol. 848, no. 1-3, pp. 24-33, 2008.

[26] R. M. F. Batista, S. P. G. Costa, E. L. Malheiro, M. Belsley, and M. M. M. Raposo, "Synthesis and characterization of new thienylpyrrolyl-benzothiazoles as efficient and thermally stable nonlinear optical chromophores," Tetrahedron, vol. 63, no. 20, pp. 4258-4265, 2007.

[27] K. Srinivas, S. Sitha, V. J. Rao, and K. Bhanuprakash, “Secondorder nonlinear response in mono- and di-substituted triazine derivatives: a combined experimental and theoretical analysis," Optical Materials, vol. 28, no. 8-9, pp. 1006-1012, 2006.

[28] B. Z. Chen, M. Z. Wang, Q. F. Luo, and H. Tian, "Novel bisthienylthene-base photochromic materials with photoregulating fluorescence," Synthetic Metals, vol. 137, no. 1-3, pp. 985-987, 2003.

[29] T. Koshido, T. Kawai, and K. Yoshino, "Novel photomemory effects in photochromic dye-doped conducting polymer and amorphous photochromic dye layer," Synthetic Metals, vol. 73, no. 3, pp. 257-260, 1995.

[30] T. C. Lin, Y. J. Huang, B. R. Huang, and Y. H. Lee, "Synthesis and two-photon properties of a multi-polar chromophore based on tetra-quinoxalinylethylene scaffold," Tetrahedron Letters, vol. 52, no. 50, pp. 6748-6753, 2011.
[31] D. M. Song, K. H. Jung, D. M. Shin, and J. H. Moon, "Photochemistry of chalcone and the application of chalconederivatives in photo-alignment layer of liquid crystal display," Optical Materials, vol. 21, no. 1-3, pp. 667-671, 2003.

[32] P. Wen, L. Wang, A. Zhang, X. D. Li, and M. H. Lee, "Synthesis and properties of novel photosensitive poly(arylene ether sulfone) containing chalcone moiety in the main chain," Materials Chemistry and Physics, vol. 126, no. 3, pp. 832-835, 2011.

[33] R. J. Anto, K. Sukumaran, G. Kuttan, M. N. A. Rao, V. Subbaraju, and R. Kuttan, "Anticancer and antioxidant activity of synthetic chalcones and related compounds," Cancer Letters, vol. 97, no. 1, pp. 33-37, 1995.

[34] B. P. Bandgar, S. A. Patil, R. N. Gacche et al., "Synthesis and biological evaluation of nitrogen-containing chalcones as possible anti-inflammatory and antioxidant agents," Bioorganic \& Medicinal Chemistry Letters, vol. 20, no. 2, pp. 730-733, 2010.

[35] A. M. Asiri, "Synthesis and characterization of dyes exemplified by 2-arylidene-1-dicyanomethyleneindane," Dyes and Pigments, vol. 42, no. 3, pp. 209-213, 1999.

[36] B. H. Lee, J. H. Kim, M. J. Cho, S. H. Lee, and D. H. Choi, "Photochromic behavior of spiropyran in the photoreactive polymer containing chalcone moieties," Dyes and Pigments, vol. 61, no. 3, pp. 235-242, 2004.

[37] Y. W. Ho, "Synthesis of some new azo pyrazolo[1,5$a]$ pyrimidine-thieno[2,3-b]pyridine derivatives and their application as disperse dyes," Dyes and Pigments, vol. 64, no. 3, pp. 223-230, 2005.

[38] Y. W. Ho and W. H. Yao, "The synthesis and spectral characteristics of novel 6-(2-substituted-1,3,4-oxadiazol-5yl)-2-phenylthieno[2,3- $d$ ]pyrimidine fluorescent compounds derived from 5-cyano-1,6-dihydro-4-methyl-2-phenyl-6thioxopyrimidine," Dyes and Pigments, vol. 82, no. 1, pp. 6-12, 2009.

[39] Y. W. Ho and M. C. Suen, "Synthesis and structure of novel thieno[2,3-d]pyrimidine derivatives containing 1,3,4oxadiazole moiety," Journal of the Chinese Chemical Society, vol. 56, no. 2, pp. 408-415, 2009.

[40] J. Koh and A. J. Greaves, "Synthesis and application of an alkaliclearable azo disperse dye containing a fluorosulfonyl group and analysis of its alkali-hydrolysis kinetics," Dyes and Pigments, vol. 50, no. 2, pp. 117-126, 2001.

[41] Standard Methods for the Determination of the Colour Fastness of Textiles, The Society of Dyes and Colourists, Bradford, UK, 3rd edition, 1962.

[42] J. J. Chen and I. J. Wang, "Synthesis and colour assessment of some 3-cyano-4-pyrenyl-6-substituted-2-pyridone derivatives," Dyes and Pigments, vol. 29, no. 4, pp. 305-313, 1995.

[43] K. McLaren, "CIELAB hue-angle anomalies at low tristimulus ratios," Color Research \& Application, vol. 5, no. 3, pp. 139-143, 1980.

[44] Y. W. Ho and C. T. Yao, "Synthesis of some new 6,8disubstituted 7,8-dihydropyrimido[2,3:4,3] pyrazolo[1,5- $a$ ] pyrimidines and 6,7,8-trisubstituted pyrimido[2,3:4,3] pyrazolo[1,5-a]pyrimidine derivatives," Journal of the Chinese Chemical Society, vol. 50, no. 2, pp. 283-296, 2003.

[45] M. Jerry, Advanced Organic Chemistry, Wiley, New York, NY, USA, 1985.

[46] I. A. Fedyunyayeva, O. P. Klochko, O. M. Semenova et al., "The synthesis, structure and spectral properties of new longwavelength benzodipyrroleninium-based bis-styryl dyes," Dyes and Pigments, vol. 90, no. 2, pp. 201-210, 2011. 
[47] E. Horiguchi, K. Shirai, J. Y. Jaung, M. Furusyo, K. Takagi, and M. Matsuoka, "New syntheses and spectral properties of diazepine flourescent dyes with non-planar molecular structure," Dyes and Pigments, vol. 50, no. 2, pp. 99-107, 2001.

[48] K. Richter, "Cube-root color spaces and chromatic adaptation," Color Research \& Application, vol. 5, no. 1, pp. 25-43, 1980.

[49] K. McLaren and P. F. Taylor, "The derivation of hue-difference terms from CIELAB coordinates," Color Research \& Application, vol. 6 , no. 2, pp. 75-77, 1981. 

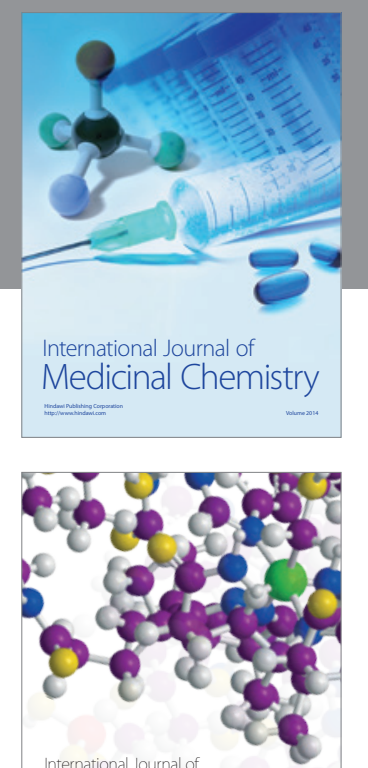

\section{Carbohydrate} Chemistry

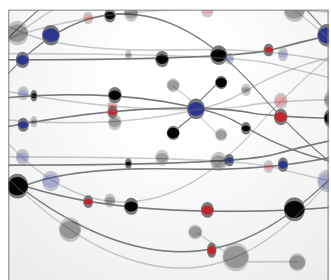

The Scientific World Journal
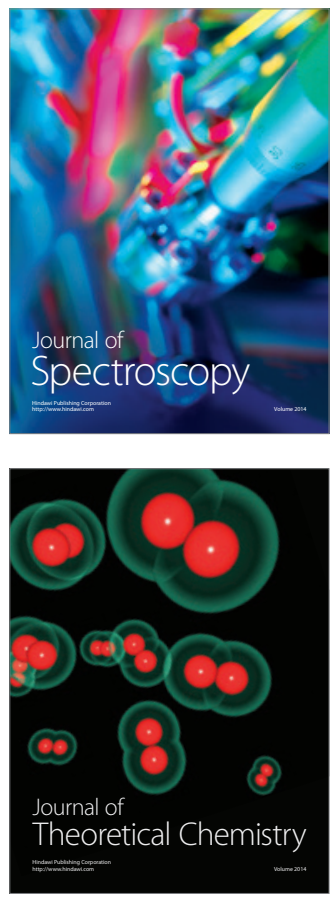
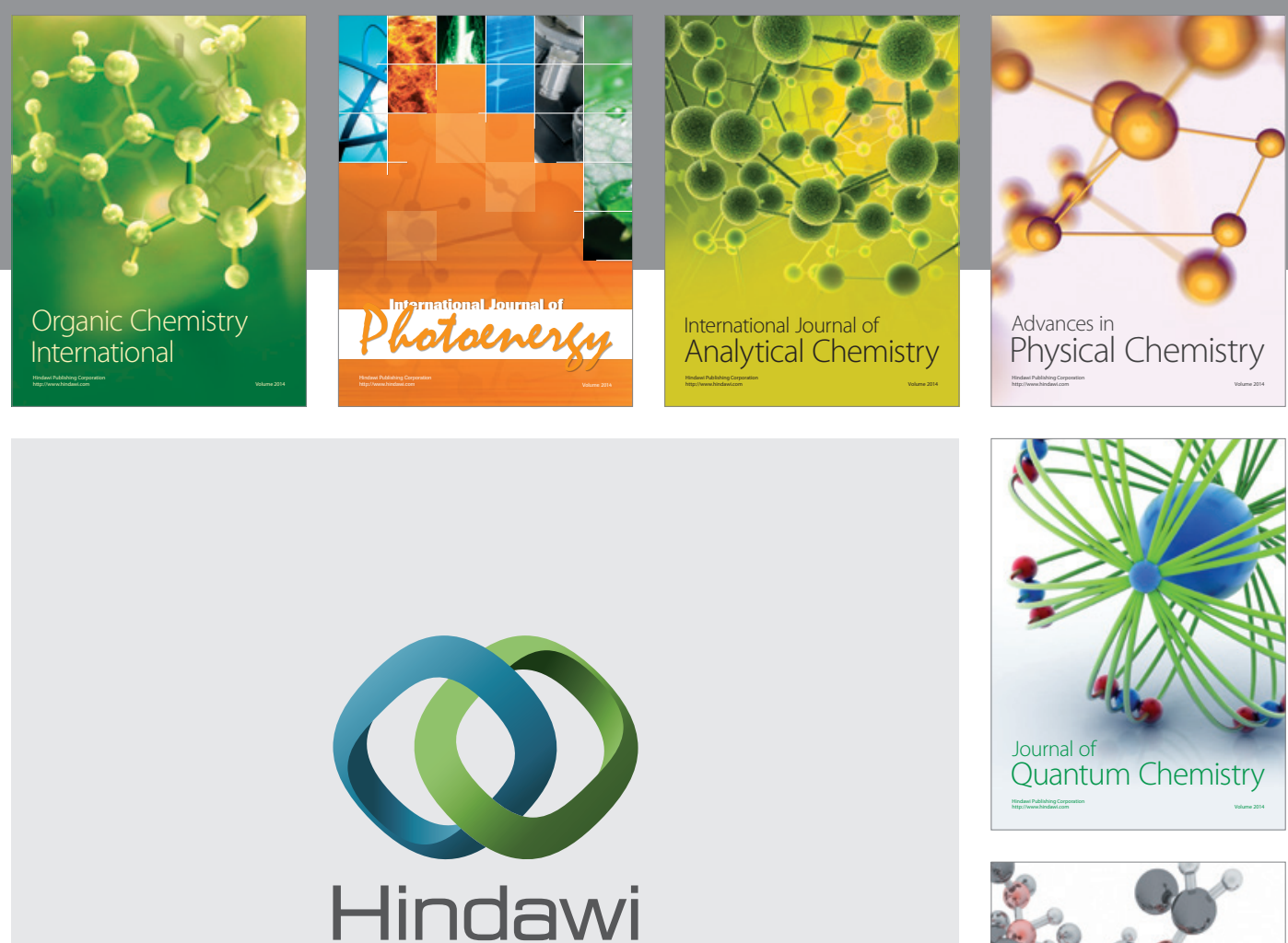

Submit your manuscripts at

http://www.hindawi.com

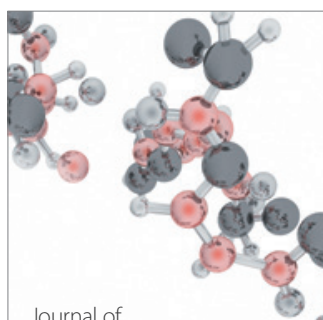

Analytical Methods

in Chemistry

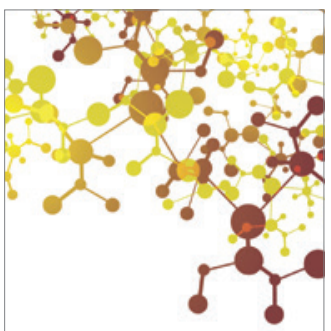

Journal of

Applied Chemistry

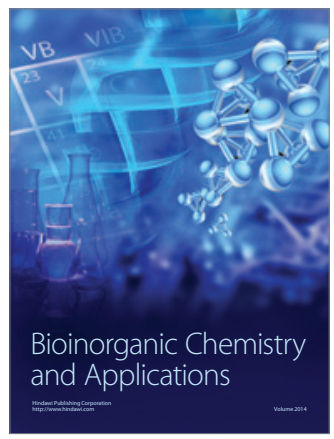

Inorganic Chemistry
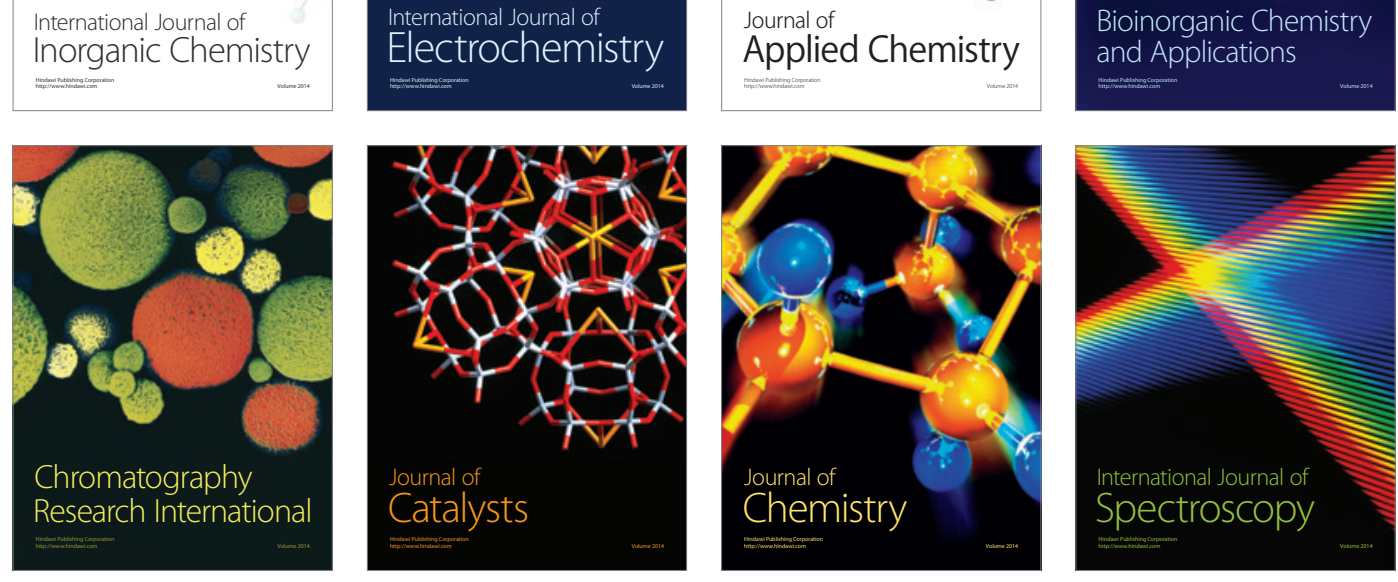